\title{
Violencia y comunicación desde la perspectiva analítica de la imagen

\section{Violence and Communication}

Editores: José Antonio MINGOLARRA, Carmen AROCENA Y ROSa MARTÍN

Reno: University of Nevada, 2012.

205 páginas.

ISBN: 978-1-935709-22-0.

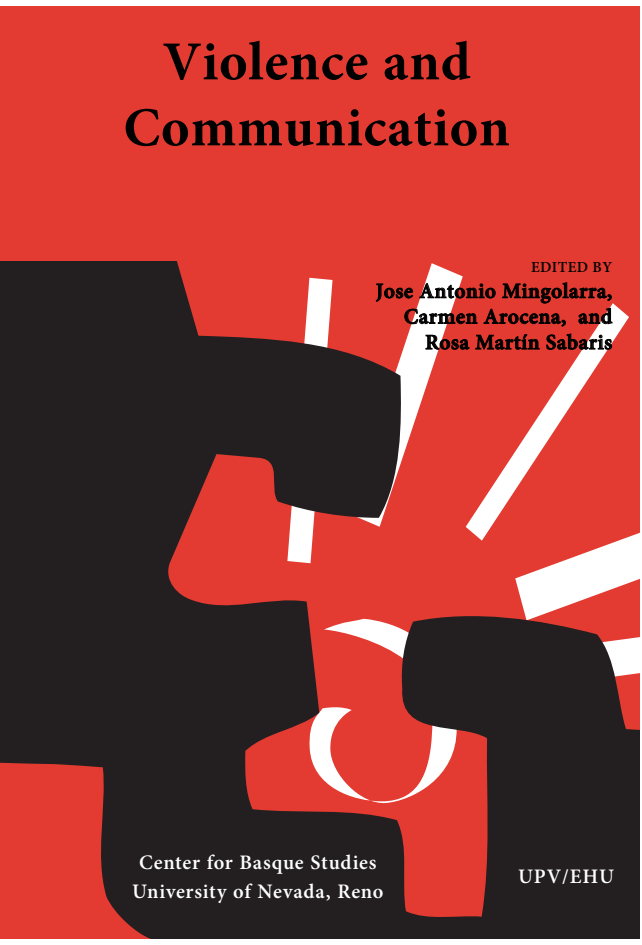

\section{Dra. Guillermina FRANCO- ALVÁREZ*}

Profesora Titular. Departamento de Periodismo y Comunicación Audiovisual. Universidad Carlos III de Madrid. gfranco@hum.uc3m.es

Estamos ante un libro, publicado en lengua anglosajona, coeditado por la Universidad de Reno y la Universidad del País Vasco y liderado por José Antonio Mingolarra, Carmen Arocena y Rosa Martín Sabaris. La publicación ofrece un marco de análisis de la violencia apoyada en los discursos cinematográficos, audiovisuales y de las imágenes fijas reproducidas preferentemente en los medios sobre los periodos de vivencia y de violencia coexistentes con la banda terrorista ETA en el País Vasco. En este texto se abren formulas de aliento para encontrar nuevas maneras de convivencia que sirvan para entender que todo lo vivido queda en la memoria individual y del colectivo del País Vasco.

Por este motivo, en las 210 páginas de esta obra se expone una reflexión comprometida donde la representación de la violencia en los medios es el espacio en el que coinciden casi los nueve capítulos de los que consta. 
El primero, de Imanol Zumalde, incide en las distintas formulas desde las que se aborda la violencia y propone un análisis desde la efectividad y significación de los símbolos. En las páginas que siguen Zumalde describe los mecanismos formales que surgen de aquellos modelos estéticos donde las descripciones audiovisuales de la barbarie son encontradas. Una vez establecidas las bases para la interpretación del fenómeno de la violencia, analiza su expresión en la confrontación con lo diferente. Concluye este análisis con el modo en que la violencia de ETA es representada por los medios de comunicación del País Vasco, abriendo así la puerta a la regeneración de un nuevo cuerpo social mediante la resistencia y el perdón de las víctimas.

Asimismo, en el capítulo dos Imanol Zubero se centra en la construcción del extraño y la violencia social. Para ello, se explicita como la limpieza étnica, la eliminación de lo diferente es sólo posible a partir de las ruinas de una comunidad de mutua aceptación. Este autor reclama la necesidad de incentivar procesos de inclusión fundados en la relevancia política y ética asociadas a la conciencia de coexistencia en un mismo espacio.

La violencia contra las mujeres es otra importante área de estudio en la que estas expresiones de violencia, si bien no siempre evidentes y visibles, pueden resultarnos constantes. En este sentido, Carmen Arocena y Nekane Zubiaur, refieren en el capítulo 3 esta violencia invisible con la intención de expresar que la violencia contra la mujer no está representada de manera explícita en los medios de comunicación. Establecen como todavía hoy el acceso a una libre y verdadera expresión de la naturaleza intelectual física y sexual de la mujer se encuentra predeterminada por la dialéctica entre lo visible y lo invisible que la mirada masculina propicia en los medios.

El objetivo del capítulo cuatro de Alfonso Dubois es reflexionar sobre las referencias imprescindibles para entender los actuales enfrentamientos y contribuir a una comunicación cuyo propósito sea difundirlos en las condiciones más oportunas y específicas. Este autor acentúa la urgencia de interpretar los vínculos entre pobreza y conflicto como elemento clave. Estos conflictos han visto como sus representaciones mediáticas se convertían en acontecimientos en sí mismos. Esta es una cuestión de comprensión acerca de las relaciones causales entre la guerra civil, la pobreza, la desigualdad y el terrorismo internacional que han modificado las estrategias de seguridad nacional e internacional.

Asimismo en el siguiente capítulo, Garitaonandía, Garmendía y Casado, a partir de las divergencias entre los distintos países, matizan que la mayoría de los medios ignoran las posibilidades que Internet ofrece a los menores y centran su discurso en las amenazas existentes ligando Internet con la violencia, el acoso o la pornografía. En definitiva, acometen el rol de la violencia en internet estudiando como los medios contribuyen a la configuración de la imagen de Internet y su repercussion en la percepción por parte de los padres de la web.

En el capítulo seis Juan de Dios Uriarte demuestra con precisión como se opone resistencia a cualquier indicio de venganza personal. Lograr esto requiere que la actitud de un colectivo este sustentado en la cohesión social, la identidad cultural, la honestidad gubernativa y la gestión comunicativa y además en un importante apoyo para las víctimas pues una vez el daño haya sido reparado estarán en posición de conceder el perdón.

Los capítulos que restan analizan más claramente el modo en el cual los medios de comunicación han dirigido políticamente los acontecimientos violentos en el País Vasco. Así pues, los autores Esparza y Parejo, en el capitulo siete, parten del atentado ocurrido el 27 de junio de 1960 que supuso la muerte de la niña, Begoña Urroz. El secreto impuesto sobre este suceso por ETA y la dictadura de Franco hizo de este acto un lugar oscuro en la memoria colectiva. Los autores aquí explican detalladamente como la modulación de la visibilidad es una característica básica de los regímenes totalitarios y como una aparición en los medios, 
especialmente en los medios audiovisuales, permite la visibilidad de este tipo de acontecimientos.

En cambio, en el capítulo ocho, acerca de la prensa en el País Vasco y el terrorismo, los profesores Armentia y Caminos claramente indican su enfoque demostrando los pasos seguidos por esta desde la mera información sobre los atentados hasta la condena de los mismos.

Y ya como conclusión de este libro, el argumento de Moreno se basa en el hecho de que la información política en el País Vasco ha estado polarizada y gobernada por patrones de seriedad consecuencia de la experiencia terrorista. En este sentido, en las últimas décadas ha sido difícil encontrar prácticas humorísticas en la vida pública. No obstante, la situación actual es diferente, ya que empiezan a surgir programas humorísticos tales como el programa Vaya semanita de la ETB con un alto índice de audiencia. Este investigador analiza a través de grupos de discusión el impacto del programa y cómo interpretan su mensaje. El resultado final demuestra que gracias a la actitud cómica esa información de entretenimiento muestra en la medida que este tipo de programas, funciona y ayuda a reforzar ciertos estereotipos sobre la política vasca, sobre todo aquellos compartidos por la mayoría de la población.

En definitiva, este libro nos aporta un análisis comparado de la violencia y la comunicación como un proceso incompleto, arduo y complejo en el que esta obra busca demostrar ciertos aspectos genéricos y particulares acerca de la expresión y representación de la violencia especialmente de la violencia terrorista en el País Vasco. 